EXEMPLARIa Classica

Journal of Classical Philology

23, 2019, $\mathrm{xx}-\mathrm{xx}$

ISSN 1699-3225

\title{
DIALOGUES BETWEEN GENRES. THE SELF-AWARENESS OF FLAVIAN LITERATURE ${ }^{*}$
}

\author{
Cecilia CRIAdo \\ University of Santiago de Compostela \\ cecilia.criado@usc.es
}

This volume is a collection of papers presented at the conference I generi letterari nell'età dei Flavi. Canoni, trasformazioni, ricezione, held in Turin, September 2013. As is inevitably the case with collective books in which studies delivered at meetings of researchers are published, the volume suffers from a certain imbalance; papers on the epic genre practically equal in number those devoted to other genres (literary history, encyclopaedism, oratory, epigram and occasional poetry).

As Federica Bessone and Marco Fucecchi point out in the Introduction, the aim of this book is not to offer theoretical redefinitions of the concept of 'genre' but to show the complex interrelations that the Flavian poets establish between the genres consecrated by their predecessors. Many of the contributions herein give ample space to immanent literary history. This is logical, in the sense that literary self-consciousness is a prototypical feature of the Flavian authors. They proudly recognise the scope of their innovations and their ability to confer the status of high literature on the new genres that they create or recreate; and, above all, they are aware of their mastery in putting polyeideia and uarietas into practice. All this means that, in the Flavian age, the boundaries between genres are blurred to an unprecedented extent. Yet it is also the reason why Flavian authors adopt a constant self-positioning towards previous and contemporary Greek and Roman production and, hence, through their explicit or oblique literary statements, that they are reliable spokespersons of an immanent approach to the history of Greco-Roman literature.

$1^{*}$ F. Bessone - M. Fucecchi (eds.), The Literary Genres in the Flavian Age. Canons, Transformations, Reception, Berlin and Boston : Walter de Gruyter, 2017, 361 pp., ISBN $978-$ 3-11-053443-6.This review article forms part of the Research Project Oedipodioniae Thebae. Biblioteca digital grecorromana sobre la guerra civil (Thebas) (FFI2015-68599-R MINECO/ FEDER), of which I am the principal researcher, and also of the Grupo de Investigación de Estudios Clásicos y Medievales (GI-1908 Xunta de Galicia) of the University of Santiago de Compostela, to which I also belong. 
The first section of the book, Genres and Literary History, is taken up by the authors Mario Citroni and Thomas Baier. In his chapter, "Antiqui, Veteres, Novi: Images of the Literary Past and the Impulse to Progress in the Cultural Program of Quintilian", Citroni argues against the conception, still prevalent today, that Quintilian is a 'classicist' due to his advocacy of a formal model pertaining to the past and his constant stressing of the need for a measured balance between opposites. Citroni holds that this preconception does not have a strong basis of support, or that, at least, it is an issue of such complexity that simplifications are inadvisable. Quintilian uses the word uetustas to allude to erroneous linguistic uses or a lack of polish on the part of an author like Lucilius (on whom he otherwise bestows high praise), but also to point out that archaism can carry associated maiestas, dignitas and delectatio. Likewise, he does not expatriate from good literary practice the pleasure inherent in nouitas nor does he give his approval to the production of works that are ill-suited to the modern development of ars. In short, he does not argue for a return to the classicism of the past, and neither does he deny the importance of ornatus, in that he recognises that this is an essential element of contemporary eloquence. His ultimate objective is to give an impulse to innovation (including lexical developments) as a means of avoiding the decadence of eloquentia.

Th. Baier also deals with Quintilian ("Quintilian's Approach to Literary History via Imitatio and Vtilitas"). The first pages of his chapter contain suggestive reflections on issues of concern to teachers and researchers of the literature of any language. He questions the idea of literary history based on the classification of literature according to literary genres or literary ages, and that ignores the role that the reader plays in the creation of the meaning of a literary text. It is a fact that, since H.R. Jauß's Rezeptionstheorie, the role of the author has been relegated in importance and the study of the process of production has lost ground to the function and effect of literary works on the reader. Baier sees in Quintilian a forerunner of such a way of seeing literature. In book 10 of the Institutia Oratoria, he offers a classification of Greek and Roman authors in which pragmatic ends prevail above value judgements, that is, he (Quintilian) stresses the utilitas of these authors for the future orator who has to practice selective imitation.

Like Citroni, Baier argues against the communis opinio that Quintilian is a conservative. On the contrary, he considers him "an advocate of permanent innovation" (p. 55). When Quintilian expresses his certainty that everything has already been invented and that, therefore, the task must be to seek excellence in innovation, he differs from Aristotles' theory of art, which accommodated invention and imitation to the same extent; but he also differs from Cicero's static interpretation of literature, since the latter advocated 
the preservation, although also the adaptation, of an inherited culture that, being superior, could not be bettered. In Baier's opinion, the importance that Quintilian confers on the idea that utilitas is that which stimulates good imitation has Epicurean tones through the mediation of Lucretius (5.1029f.) and Horace (epist. 2.1.93).

Sandra Citroni Marchetti and Andrea Balbo are both experts in Roman oratory, rhetoric and philosophy, and are the authors of the two chapters that comprise the second section of the volume, Encyclopaedism and Oratory. The concept of usefulness is once again emphasised by Citroni Marchetti ("Contingat aliqua gratia operae curaeque nostrae: an Ethic of Care in the Naturalis Historia"). She analyses the relevance that care ('cura') has in programmatic statements in Pliny the Elder's Naturalis Historia. He constantly alludes to his care in selecting the books he used as sources and in his direct and meticulous research into certain facts. In this anxia ... cura (nat. 6.23) he sees himself as someone continuing the work of the ancient authors who, despite their achievements, were the object of criticism and ingratitude by readers because their subject matter involved humble and neglected aspects of nature (p. 68). In his defence, always with modesty, he argues that his goal, as was the case with the ancient scholars, is that his research be of use in the lives of his contemporaries (nat. 25.22). Citroni observes that "Pliny does not present himself as a physician, but as an intermediary between man and nature" (p. 72), always showing his feelings of compassion towards the sufferings to which Man is exposed; in fact, he uses the term cura most frequently with reference to agricultural activities and medical matters. Although with due caution, Citroni relates Pliny's sympatheia towards the vulnerability of the other, with the moral philosophy developed in the 1980s, the 'ethics of care'. This allows her to see the extent to which Pliny distances himself from the patriarchal 'care' dominant in warlike contemporary Rome. As in many other passages, in the Mother Earth myth (nat. 2.154-9) there is a reflection on the suffering caused by this warrior-paternalism.

Andrea Balbo's contribution is valuable because, although there are many studies on partial aspects of the oratory of the first century C.E., a comprehensive study is still lacking. In his chapter ("Roman Oratory and Power under the Flavians: Some Case Studies from Pliny the Younger"), he explores the real situation of Flavian oratory and its connection to Flavian imperium. Both are questions on which we have little data, since no complete speech is preserved; Quintilian quotes no living orator and Pliny is reluctant to speak of the period 81-92 B.C. It is well known that both the gradual transition from the system of quaestiones to a new kind of trial, the cognitio extra ordinem, and the restrictions on freedom of speech were 
determinant in the decay of oratory. Nevertheless, Balbo adduces two letters from Pliny, to Suetonius and to Voconius Romanus, in which he informs them, respectively, about two of his trials: the first in defence of Iunius Pastor and the second in defence of Arrionilla. The information provided by Pliny, Balbo argues, shows that the civil cases (or centumviral trials) may have been more dangerous, and that they had a more marked political tone than we might normally think.

The papers of Alberto Canobbio ("Bipartition and non-Distinction of Poetical Genres in Martial: magnum vs paruum") and Alfredo Mario Morelli ("Catullus 23 and Martial. An Epigrammatic Model and its 'Refraction' throughout Martial's Libri") comprise the third section of the volume, Tradition and Poetics of the Epigram. Undoubtedly, the Callimachean bipartition magnum / paruum supposes an over-simplification in terms of a thorough understanding of the Greco-Roman literary system. Despite this, it enjoyed great success as an eidetic view in the Roman literature of the Low Republic and of the Augustan age. Martial also recalls this Callimachean pattern in numerous epigrams. However, Canobbio analyses passages in which the poet shows his awareness that the boundaries between epic, tragedy and lyric are being blurred (e.g., epigr. 7.23.1f. and 8.18) as well as his conviction that the epigrammatic genre can incorporate elements from many other minor genres, namely, satire, comedy, elegy and bucolic (see epigr. 8.3). That is, he integrates his epigrammatic production with the other genres and, in this way, he manages to legitimate his poetry as literature. An even more modern and drastic way of thinking about the relationship between literary genres is offered by Statius, as well as Valerius Flaccus and Silius Italicus, who, using the contaminatio, move with mastery and selfawareness between magna and parua poetical forms in their epic poems.

In his chapter, Morelli focuses on the thematic debt of Martial to Catullus' poems, his main genre-model. His arguments and conclusion are stimulating but his discursive line is difficult to follow and, perhaps, a little more signposting in this regard would have been useful to guide the reader and facilitate a fully instructive reading of the paper. He points out the mastery of Martial's literary strategies regarding imitation and the role played by this to provide "the reader with landscape for creating a path throughout the liber" (p.131). Martial's technique consists of either making use, within a single poem, of different compositions by Catullus in which there is a thematic affinity or, on the contrary, sticking to a single Catullan poem and alluding to it in several epigrams. The first imitative procedure is found in the use that Martial makes in epigr. 1.92 of the thematic continuity within Catul. 15, 21, 23, 24, 29, 94, 105, 114 and 115, poems in which Furius, Aurelius or Mamurra are the object of Catullus' stinging words. Thus, the Mamurianus 
of Martial is transformed into an alter ego of the Catullan Aurelius of poem 21, the Furius of poem 23, and the Mamurra of poems 29, 94, 105, 114 and 115. On many other occasions we find this procedure of the imitation of several Catullus compositions in which the epigrammatist feels as if this were a coherent whole. When Martial uses the second imitative technique, he subjects a single poem by Catullus to 'diffraction' that becomes the object of close imitation in several epigrams. This happens with more frequency in Book XI where the motifs and diction of Catull. 23 appear in epigrams 31, 32 and 56 (see also 12.32).

Elena Merli opens the fourth section of the volume, Occasional Poetry and Literary Genres, with a chapter in which she studies the festinatio in Ovid (in whose Epistulae from Tomis can be found the earliest examples of festinatio), Antipater of Thessalonica, Martial and Statius. Merli argues that, although there are similarities, festinatio is not the same as improvisation because festinatio is the product of a professional and skilled poet. Martial shows this with his locution festinatas coronas (epigr. 13.126), with which the poet seems to warn the reader that, in his hasty compositions, festinatio is a guarantee of the quality of his collection of poems. The topos in Statius present greater complexity. In silv. 1 praef. 1-7 and 11-15, although proud of his technical mastery and virtuosity, he expresses the fear that celeritas might be the object of negative criticism when the poems are published in volume form. En epist. 1.26 and 1.1.1, Pliny shows a similar concern; he reflects on the fact that a collection of poems that aspires to the condition of literature must be clearly connected with the poetics of labor limae (p.149). However, Statius, unlike Pliny, states that he has not submitted his festinati pieces to correction. He, after all, is aware that his Thebaid and his unfinished Achilleis guarantee his mastery of the quintessential high genre.

The title of Alessia Bonadeo's chapter is "Scattered Remarks about the 'non-Genre' of Statius' Siluae. The Construction of a Minor Canon". However, it should be noted that, when she qualifies the Siluae as a "nongenre', this refers only to the difficulty of establishing the generic identity of these compositions. Indeed, the instability of the lexicon employed by Statius himself to refer both to his single poems and to his collection seems to indicate that we are dealing with a "genre still under construction" (p.156). Bonadeo, as well as Merlin and Newlands in their chapters, underlines Statius' concern that educated readers might criticise the celeritas of these compositions, and she cites here, as does Merli, the well-known Silv. 1 praef.1-15 in which the poet uses the same stratagem of legitimation as Martial, that is, to adduce as precedential praelusiones the prestigious Batrachomachia of Homer and the Culex, attributed to Virgil. Bonadeo's conclusion coincides with that of Merli: both the Batrachomachia and the Culex were juvenile experiments, 
whereas Statius had already composed a major poem before he wrote his ludic poetry.

Carole E. Newlands deals, in part, with the same topic (namely, Statius' anxiety as to possible criticisms, as shown in Silv. 1 praef. 15-19 and the justification of his improvisational style in 2 praef. 7-12) although she broadens the perspective in her chapter "The Early Reception of the Siluae: from Statius to Sidonius". Newlands opens her essay by affirming that "the reception of Statius' Siluae begins with Statius himself" (p. 167) and in pages 172-6 she discusses the interchanges and thematic and generic interplay between the Thebaid and the Siluae, a question which has certainly become the object of scholarly attention only very recently. Newlands goes on to address the impact of Statius' Siluae on Sidonius Apollinaris, the first author to make an explicit reference to the Siluae, and this at a late date, the fifth century. It is especially in carm. 22 where, during the description of the villa of his friend Pontius Leontius, he takes the Silvae as the central model. However, as Newlands shows, the Statian festinatio is not the feature that most interests Sidonius when he imitates Statius, but rather the continuity between Statius' epic and his extemporaneous poems: "the poetics of the Thebaid and of the Silvae remain intertwined in Sidonius' poem" (p. 182). Sidonious' perspective is, in short, the same as that of Statius itself.

As already mentioned, almost half of the volume (144 pp.) focuses on epic genre, to which three of the seven sections are devoted, these being: Models and Transformations of the Epos, War and Generic Tensions and Epic and other Genres. In the first of these sections, Jacqueline FabreSerris presents the problematical issue of the traditional celebratory function of epos in Valerius Flaccus' Argonautica, and Andrew Zissos brings to light new innovations by Valerius in respect of his fundamental 'exemplary model', Apollonius of Rhodes.

In "The Argonautica of Valerius Flaccus and the Latin Tradition on the Beginning and End of History (Catullus, Virgil, Seneca)", Jacqueline Fabre-Serris raises the problematical question that underlies Valerius Flaccus' ideological interpretation of the myth of the inauguration of sea navigation. As we know, Catullus in Carmen 64, Horace in Carmina 1.3, and Seneca in Medea, all offered a negative reading of this event and, thus, of the evolution of human history. On the contrary, Valerius' Argonautica seems to present Jason's expedition as the beginning of a promising period in the history of mankind that, apparently, has the acquiescence of a positive fatum. However, in the prophecy of Jupiter, he presents himself as a mere arbitrator of the future, who will decide whilst on the march which empires will dominate the world (1558-60). Fabre-Serris contrasts his ambiguity, "which in fact contravenes the very idea of destiny" (page 198), with the deep knowledge 
of destiny that the Virgilian Jupiter possesses and which proclaims that the imperium of the world will be up to Rome. So, from an ideological point of view, Valerius refuses to take a position with respect to human fate; that is, he does not adopt the negative sense of Catullus and Seneca, but neither does he adheres to the positive view of Virgil.

It is an acknowledged fact that Valerius' Hypsipyle owes much to Virgil's Dido and that, in turn, Virgil's Dido owed much to Apollonius' Hypsipyle. Yet Hysipyle in the Argonautica is invested with a new heroic status and her story continues to be significant once the Lemnian episode has finished. Faced with the prevalence of the erotic features of the Apollonian Hypsipyle, Valerius underscores her filial devotion, her masculine heroism and her feminine virtuosity; but, in addition, she, unlike Dido, is an exemplar of self-control. Her female activity is highlighted by the fact that, when Jason decides to leave Lemnos for Colchis, she gives him a cloak as a gift. Unlike what happens in Apollonius' Argonautica, it is she who has made this cloak and, unlike what other women in ancient epic do, she herself decorates the garment with her own story, specifically, with her earlier valiant rescue of her father Thoas. Hypsipyle, echoing the Virgilian episode in which Aeneas gives Dido the sword with which she will commit suicide, gives Jason the sword that belonged to her father. As Zissos asserts, "she demonstrates that she will not follow the same path as Dido", (p. 218) who is her "negative model" (p. 224). Zissos explores the retrospective mention of the Hypsipylean cloak in book 3 when, after the accidental death of Cyzicus at the hands of Jason, the latter places on the king's pyre the garment given to him by Hypsipyle (vv. 340-2). Obviously, this funereal gesture recalls Aeneas laying on Pallas' corpse the cloak given by Dido. But Valerius, by showing Jason getting rid of a love gift made just two days previously, shows that, while Hypsipyle is a character that promotes the unification and preservation of the family, Jason's activities lead towards fragmentation and destruction. In the words of Zissos, "the Lemnian tale constitutes one of the most striking reversals of gendered expectation in all of ancient myth" (page 213).

Helen Lovatt, R. Joy Littlewood, Raymond Marks and Alison Keith are the authors of the following section on epic, War and Generic Tensions. We are well aware of Lovatt's interest in the visual nature of epic. In "The Beautiful Face of War: Refreshing Epic and Reworking Homer in Flavian Poetry", she precisely (and challengingly) notes the beauty of the war in Statius' Thebaid, an aspect which, however, neither Valerius Flaccus nor Silius Italicus mention. Statius, on the contrary, does contemplate the possibility of a beautiful side of war (see, for example, pulcher adhuc belli uultus, Theb. $8,402-5)$. Lovatt underlines the influence of the Homeric scenes of soldiers on the march as if they were earns of corn, although she also recognises 
the echoes of Virgil and Tacitus' metaphor of the Italian earth flowering with warriors (and even, she suggests here, a Lucanian flavour). Statius, on this occasion, it is more Homeric than Virgilian and the juxtaposition of beauty and destruction, of force and terror, contributes to the fundamental ambivalence of the sublime in the Thebaid (p.233).

Again, and inevitably in a study of Flavian literary production, we see the notion of the mixture of genres in R. Joy Littlewood's chapter, "Epic on the Edge: Generic Instability at the Pivotal Centre of Silius' Punica (10.33671)". After the crushing victory of Hannibal over the Roman army at the battle of Cannae, the Carthaginians take for granted the conquest of Rome. However, Juno, knowing that Jupiter will never allow her protégé to be the Lord of Rome, asks the Somnus to send Hannibal a dream that makes him desist from his advance (10.335-7); shocked by the nightmare, Hannibal loses the opportunity for victory. Littlewood suggests that, with this dream, "the poet creates an illusion of generic instability for dramatic purposes" ( $\mathrm{p} 254$ ). Above the Homeric model ( $\mathrm{Il}$. 14.153-353) it is that of Ovid's Morpheus that prevails: Morpheus, at the behest of Juno, adopts the form of the deceased Ceyx and communicates his death to his wife Alcyone. There will be no hope, concludes Littlewood, either for Ovidian Ceyx or for Silian Hannibal, who resembles one of Ovid's most vulnerable women.

Silius' appropriations of lyric material is the theme of Raymond Marks' chapter("Silius, Sicily, and the Poetics of Generic Conflict: Grosphus in Punica 14.208-17"). Although book 14 focuses on military affairs in Sicily, Silius introduces elements drawn from non-epic poetic traditions. Marks examines the use that the poet makes of Callimachus' Aetia, Horace's Carmina 2.16 and Ovid's exilic poetry in the description of the shield of Grosphus, a Roman ally from Agrigento. Silius' aim, Marks holds, is to assert the authority of "his 'big' epic over 'small' genres" (p.282) but, at the same time, his display of erudition underlines that his literary program is faithful to the Callimachean and neoteric cura. The name Grosphus calls to mind Pompeius Grosphus that Horace presents in carm. 2.16 living peacefully in Sicily. Also Pindar, Callimachus and Ovid make their presence felt in Grosphus' shield, since on it is etched the bronze bull of Phalaris. Silius frequently associates Sicily with non-epic traditions but, with the arrival of the Romans, it is forced to abandon its pastoral tradition. Grosphus, but also Daphnis in 12.462-76, represent this epic transformation of Sicily. Silius reduces this generic tension with the Horatian lyric because, after all, Marcellus dedit otia mundo $(14,686)$ with his victory over the Carthaginians.

Alison Keith's chapter ("Lyric Resonances in Statius' Achilleid") deals with the presence of lyric poetry in Statius' Achilleid, a subject that has not been the object of excessive scholarly attention. She suggests that Statius' poetic program in the Achilleid was to draw on Horatian lyric and on his own Siluae in a systematic and significant way. Indeed, although the 
proem is modelled on the opening verses of the Aeneid, the word deducere (Ach. 1.7) has a strong metapoetical charge that signals Statius' intention to link his epos with the style of elegiac or lyric poetry. This is clear in the Horatian diction (carm. 2.5.20-4) that he employes in the verses in which Thetis disguises Achilles in order that his Scyrian hosts accept him as a girl. Likewise, the themes of the young hero's song (1.184-94) seem to have drawn on a Greek lyric model, in that they are better suited to a deductum carmen than to heroic epic. Horace and his delimitation between the tender music of the peaceful lyre and the martial subjects of epic (carm. 1.6) returns to make its appearance when Achilles teaches Deidamia to play the lyre (1.570-9).

$* * *$

Antony Augoustakis ("Burial Scenes: Silius Italicus' Punica and GrecoRoman Historiography") and Christiane Reitz ("Is Capaneus an Epicurean? A Case Study in Epic and Philosophy") are the authors featured in the final section of the volume, Epic and Other Genres. Augoustakis examines several episodes of burial in Punica with the goal of re-examining Silius' relationship with Polybius and Livy. His aim is to show that, in the Punica, "when it comes to burial, the distinction between Roman and non-Roman, friend and foe, civilised and uncivilised is often blurred." Hannibal's attitude towards the death of his enemies certainly reveals his complex character in this epos. After the Carthaginian victory at Cannae, Hannibal orders the Roman bodies and the corpse of Aemilius Paulus to be burnt and buried (10.535-46). Livy also recounts this episode, although the emphasis that Silius places on the pomp (funereum decus, v. 562) with which Hannibal celebrates the ceremony is absent in Livy. What's more, Silius has Hannibal deliver the laudatio funebris, as if he were the son or a kinsman of Paulus. Again, according to the version of Silius, which once more deviates from Livy's historical record, when the Carthaginians are forced to hurry back to Capua, Hannibal stops to give burial to Tiberius Sempronius Gracchus; and, finally, Hannibal exhibits similar behaviour to Marcellus and, again, unlike the version offered by Livy, the laudatio is pronounced by Hannibal, not by the son of Marcellus.

Undoubtedly, Capaneus has a belligerent and wrathful character. He is a mighty warrior but, just as Statius anticipates in the proem of the Thebaid (alio Capaneus horrore canendus, 1-45) and reiterates in book 10 (non mihi iam solito uatum de more canendum, v. 829), the Argive hero is, above all, a superum contemptor (3.602 and 9.550). In 10.902-6 he challenges Jupiter himself; this fact provokes the indignation of the rest of the gods, but the father of the gods simply laughs (risit, v. 908). Reitz asserts that both the different elements of the action of Capaneus and of the gods are tinged with the doctrine of Epicurean philosophy as known from Lucretius' De rerum natura: the 'Epicurean' Capaneus dismisses the possibility of being punished 
by the gods and Jupiter, faced with his impiety, maintains an Epicurean impassivity. However, Reitz is not in favour of interpreting literary creations as a means of conveying philosophical messages. She suggestively opts instead for endowing the false Epicurean doctrine of this passage with a metapoetic message. Statius' aim would be to demonstrate that epic is the most flexible of genres and that, therefore, it has all the other genres at its disposal, including didactic poetry.

As Bessone and Fucecchi recognised in the Introduction, research into Flavian literature and, more specifically, into Flavian epic, has increased remarkably over recent decades. However, this volume is undoubtedly necessary and represents a very significant contribution to a more comprehensive understanding of the scope of the dynamism of the genres in this specific period of the history of Roman literature. I find, however, one objection. Some of the contributors, although with different methodologies and perspectives, deal with themes which are thematically very close, and indeed arrive at analogous conclusions. This is the case, for example, with the chapters by Mario Citroni and Thomas Baier, by Alberto Canobbio and Alfredo Mario Morelli, and those of R. Joy Littlewood and Raymond Marks. Nevertheless, the authors make few references to other articles in the volume. This slight deficiency might, I believe, have been detected during editing, and the degree of cross-referencing enhanced somewhat. 